\title{
Tometes camunani (Characiformes: Serrasalmidae), a new species of phytophagous fish from the Guiana Shield, rio Trombetas basin, Brazil
}

\author{
Marcelo C. Andrade ${ }^{1}$, Tommaso Giarrizzo ${ }^{1}$ and Michel Jégu ${ }^{2}$
}

A new species of Serrasalmidae, Tometes camunani, is described from the upper drainages of the rio Trombetas basin, Pará State, Brazil. The new species is distinguished from its congeners by having neurocranium with a slight concavity at the level of the frontal bone ( $v s$. concavity absent, dorsal profile of neurocranium straight). It can be further distinguished from its congeners by having teeth with central cusp taller and acute ( $v s$. central cusp shorter and with rounded edge in T. trilobatus), a terminal mouth ( $v s$. upturned mouth in T. lebaili), and 12-26 prepelvic spines ( $v s .0-9$ in T. makue). The new species is strictly rheophilic like other species of Tometes, and occurs exclusively in the rapids of shield rivers, complex and fragile biotopes that are threatened by anthropogenic activities. An identification key to the species of the Myleus group is provided.

Uma espécie nova de Serrasalmidae, Tometes camunani, é descrita para as drenagens superiores da bacia do rio Trombetas, estado do Pará, Brasil. A espécie nova distingue-se dos congêneres pela presença de uma ligeira concavidade no neurocrânio na altura do frontal ( $v s$. concavidade ausente, perfil dorsal do neurocrânio reto). Também pode ser adicionalmente distinguido dos seus congêneres por possuir dentes com a cúspide central mais alta e cume agudo ( $v s$. cúspide central mais baixa e com cume arredondado em T. trilobatus), a boca terminal (vs. boca orientada para cima em T. lebaili), e 12-26 espinhos pré-pélvicos (vs. 0-9 em T. makue). A espécie nova é estritamente reofílica, como as demais espécies de Tometes, e ocorre exclusivamente nas zonas encachoeiradas dos rios de escudo, biótopos complexos, frágeis e ameaçados por ações antropogênicas. Uma chave de identificação para as espécies do grupo Myleus é apresentada.

Key words: Amazon basin, Herbivorous fishes, Rapids, Rheophily, Taxonomy.

\section{Introduction}

Tometes Valenciennes, 1850 is a genus of large-sized and strictly herbivorous serrasalmid fishes which reach approximately $500 \mathrm{~mm}$ SL and a weight of up to $4 \mathrm{~kg}$ (Jégu \& Keith, 2005). All valid species of Tometes are known from leftbank tributaries of the lower Amazon basin, northeastern coastal rivers of the Guiana Shield, middle and upper rio Negro, and right-bank tributaries of the upper rio Orinoco (Jégu et al., 2002a; Jégu, 2003). Species of Tometes are strictly rheophilic and exclusively inhabit rocky rapids associated with rupestral seedlings of Podostemaceae, their main source of food (Jégu et al., 2002b; Jégu, 2003). Given their habitat hyperspecificity (Brito et al., 2007), species of Tometes are especially vulnerable to the loss of lotic systems, and therefore are greatly threatened by the construction of hydroelectric dams (Junk \& Mello, 1990; Jégu \& Keith, 2005). In addition, rheophilic serrasalmids (e.g., species of Tometes, Myloplus, and Mylesinus) are very important to the traditional culture of local communities (Pagezy \& Jégu, 2002, 2003, 2010).

Valenciennes (1850) proposed the genus Tometes, based on its incisiform teeth. Ten years later, based only on information from the literature, Kner (1860) synonymized Tometes trilobatus, type-species of Tometes Valenciennes, 1850, with Myleus setiger, type-species of Myleus Müller \& Troschel, 1844 (Jégu \& Santos, 2002; Jégu et al., 2002c). However, Jégu et al. (2002c) revalidated both the genus Tometes and its type species after the examination of the type series of Tometes, plus additional specimens attributed to the genus.

Tometes, Myleus, Mylesinus Valenciennes, 1850, and Ossubtus Jégu, 1992, comprise a monophyletic assemblage based on morphological data (Jégu, 2004). Considering the same taxa, except the monotypic Ossubtus xinguense, Ortí et al. (2008) confirmed those previous results using molecular data, and

\footnotetext{
${ }^{1}$ Universidade Federal do Pará, Laboratório de Biologia Pesqueira e Manejo dos Recursos Aquáticos, Grupo de Ecologia Aquática. Campus Universitário do Guamá, Avenida Perimetral, 2651, Terra Firme, 66040-830 Belém, Pará, Brasil. andrademarcosta@gmail.com (MCA); tgiarrizzo@yahoo.it (TG)

${ }^{2}$ Institut de Recherche Pour le Développement, Biologie des Organismes et Ecosystèmes Aquatiques, UMR BOREA, Laboratoire d'Icthyologie, Muséum National d'Histoire Naturelle, MNHN, CP26, 43 rue Cuvier, 75231 Paris Cedex 05, France. michel.jegu@gmail.com
} 
also proposed the term Myleus group. Currently, Tometes comprises three valid species, the type species T. trilobatus Valenciennes, 1850, T. makue Jégu, Santos \& Belmont-Jégu, 2002, and T. lebaili Jégu, Keith \& Belmont-Jégu, 2002.

The species of Tometes described herein occurs in sympatry with three other rheophilic serrasalmids, Mylesinus paraschomburgkii Jégu, Santos \& Ferreira, 1989, Myleus setiger Müller \& Troschel, 1844, and Myloplus rhomboidalis (Cuvier, 1818) in the upper reaches of the rio Trombetas basin, at the site that is planned for construction of the Cachoeira Porteira hydroelectric dam. An identification key to the species of the Myleus group is also provided.

\section{Material and Methods}

Measurements and counts follow Jégu et al. (2002b, c). Measurements were taken point to point to the nearest $0.1 \mathrm{~mm}$ with digital calipers, and counts were taken under a stereomicroscope; both were taken from the left side whenever possible. Meristic data are given in the description. The range of counts is followed by the value observed on holotype in parentheses. Measurements of the body are given as percentages of Standard Length (SL), and subunits of the head are given as percentages of Head Length (HL). Counts of vertebrae and supraneurals were obtained from examination of two skeletonized (skel.) specimens (MPEG 23448 and MPEG 23449) and radiographs of ten alcohol preserved specimens: MPEG 23440, MPEG 23442, MPEG 23445, MPEG 23446 (3 of 6), MPEG 23447, MPEG 23450 (1 of 2), MPEG 23451 ( 1 of 2), and ZUEC 7066. Vertebral counts included the Weberian apparatus as four additional vertebrae, and the fused PU1+U1 of the caudal region counted as a single vertebrae. Vertebral counts are categorized into: predorsal vertebrae, which are all vertebrae anterior to the vertical through the first dorsal-fin pterygiophore; postdorsal vertebrae, all vertebrae posterior to the vertical through the last dorsal-fin pterygiophore; the number of vertebrae between the last dorsal-fin pterygiophore and first anal-fin pterygiophore; and the total number of vertebrae. Osteological terminology follows Weitzman (1962). The entire gastrointestinal tract (GIT) from the esophagus to the anus was removed and measured (= GITL $\pm 1 \mathrm{~mm}$ ) in eight specimens: MPEG 23448(1), MPEG23449(1), MPEG 23450(2), MPEG 23451(2), and MPEG23452(2), 90.8-382.0 $\mathrm{mm}$ SL. The relative length of the GIT (= RLGIT) was calculated as RLGIT $=$ GITL/SL. Stomach contents were preserved in $70 \%$ ethanol solution and examined under a stereomicroscope to identify food items to the lowest taxon possible.

Institutional abbreviations are ANSP, The Academy of Natural Sciences, Philadelphia; INPA, Instituto Nacional de Pesquisas da Amazônia, Manaus; MCP, Museu de Ciências e Tecnologia, Porto Alegre; MNHN, Muséum National d'Histoire naturelle, Paris; MNRJ, Museu Nacional, Universidade Federal do Rio de Janeiro, Rio de Janeiro; MPEG, Museu Paraense Emilio Goeldi, Belém; MZUSP, Museu de Zoologia da Universidade de São Paulo, São Paulo; UFPA, Universidade Federal do Pará, Belém; and ZUEC, Museu de Zoologia da Universidade Estadual de Campinas, Campinas.

\section{Tometes camunani, new species Fig. 1}

Utiaritichthys sp.: Ferreira, 1993: 24 (Brazil, Pará, rio Trombetas basin; species caught upstream of the Cachoeira Porteira).

Holotype. MPEG 23447, 224.3 mm SL, Brazil, Pará, Trombetas basin, rio Erepecuru, upstream of the Cachoeira do Chuvisco, 0059'59”'S 5604'42”'W, T. Giarrizzo, 30 Oct 2003.

Paratypes. All from rio Trombetas basin, Pará, Brazil: MPEG 23439, $248 \mathrm{~mm}$ SL, rio Trombetas, upstream of Cachoeira Porteira, 00 57'01'S 5701'13”W, M. C. Andrade \& T. Giarrizzo, 27 Feb 2011; MPEG 23440, $384 \mathrm{~mm}$ SL, rio Trombetas, Cachoeira Porteira, 0103'47'S 5702'31'”W, T. Giarrizzo, 10 Nov 2003; MPEG 23441, $276 \mathrm{~mm}$ SL, rio Trombetas, Cachoeira Porteira, 0103'47”S 5702’31'W, T. Giarrizzo, 9 Nov 2003; MPEG 23442, 98 mm SL, rio Trombetas, Iteiro Grande, rapids of Traval, upstream of Cachoeira Porteira, 0046'17'S 56 52'15"W, M. C. Andrade \& D. A. Bastos, 25 Oct 2008; MPEG 23443, 2, 247-293 mm SL, rio Trombetas, upstream of Cachoeira Porteira, 00 55'07'S 5701'36”'W, M. C. Andrade \& T. Giarrizzo, 24 Feb 2011; MPEG 23444, 3, 291-329 mm SL, rio Trombetas, upstream of Cachoeira Porteira, $00^{\circ} 55^{\prime} 07^{\prime}$ 'S 5701'36”W, M. C. Andrade \& T. Giarrizzo, 27 Feb 2011; MPEG 23445, 127 mm SL, rio Trombetas, rapids of Enseada, 0049'38'S 56 57'28'W, M. C. Andrade \& D. A. Bastos, 24 Oct 2008; MPEG 23446, 2, 212-235.4 mm SL, rio Erepecuru, upstream of Cachoeira do Chuvisco, 0059'59'S 56 04'42”'W, T. Giarrizzo, 30 Oct 2003; INPA 2310, $167 \mathrm{~mm} \mathrm{SL}$, rio Cachorro, 2 $\mathrm{km}$ above confluence with rio Trombetas, E. G. Ferreira, 28 Nov 1987; INPA 2311, 180 mm SL, rio Mapuera, Cachoeira Patauá, 0145'56”'S 5551'57'W, E. G. Ferreira, 27 Nov 1987; INPA 3639, $299 \mathrm{~mm}$ SL, rio Trombetas, Cachoeira Porteira above confluence with rio Cachorro, 0059'21'S 5704'09'W, E. G. Ferreira \& M. Jégu, 15 Apr 1985; INPA 5173, 230 mm SL, rio Trombetas, downstream of Cachoeira Quebra Pote, E. F. Ferreira \& M. Jégu, 9 Oct 1985; INPA 5176, $325 \mathrm{~mm} \mathrm{SL}$, rio Trombetas, near rio Caxipacoré, E. G. Ferreira \& M. Jégu, 5 Oct 1985; MCP 47376, 2, 208-242 mm SL, rio Erepecuru, upstream of Cachoeira do Chuvisco, 0059'59'S 5604'42'W, T. Giarrizzo, 30 Oct 2003; MNRJ 40204, 2, 211-212 mm SL) rio Erepecuru, upstream of Cachoeira do Chuvisco, 0059'59'S 5604'42'W, T. Giarrizzo, 30 Oct 2003; MZUSP 15893, 5, 201-274 mm SL, rio Mapuera, Ilha da Facada, close to the confluence with the rio Trombetas, R. M. C. Castro, 21 Jul 1979; ZUEC 7066, 236 mm SL, rio Erepecuru, upstream of Cachoeira do Chuvisco, 0059'59"S 5604'42”W, T. Giarrizzo, 30 Oct 2003; ZUEC 7067, $291 \mathrm{~mm}$ SL, rio Trombetas, upstream of Cachoeira Porteira, 0055'07'S 5701'36”W, M. C. Andrade \& T. Giarrizzo, 24 Feb 2011.

Non-type specimens examined. All from Trombetas basin, Pará State, Brazil: MPEG 23449, 910.8 mm SL, skel., Trombetas river, upstream of Cachoeira Porteira, 00 55'07'S 5701'36”W, J. R. Carvalho Jr, 2 Dec 2007; MPEG 23448, 382 mm SL, skel., rio Trombetas, upstream of Cachoeira Porteira, 00 55'07'S 5701'36”'W, M. C. Andrade \& T. Giarrizzo, 24 Feb 2011; MPEG 23452, 2, 355-382 mm SL, rio Trombetas, upstream of Cachoeira Porteira, 0055'07'S 5701'36"W, M. C. Andrade \& T. Giarrizzo, 24 Feb 2011; MPEG 23451, 2, 175-322 mm SL, rio Mapuera, upstream of Cachoeira Porteira, 01 $07^{\prime} 26^{\prime}$ 'S 57 14 '35”W, M. C. Andrade \& D. A. Bastos, 26 Jun 2008; MPEG 23450, 2, 133-206 


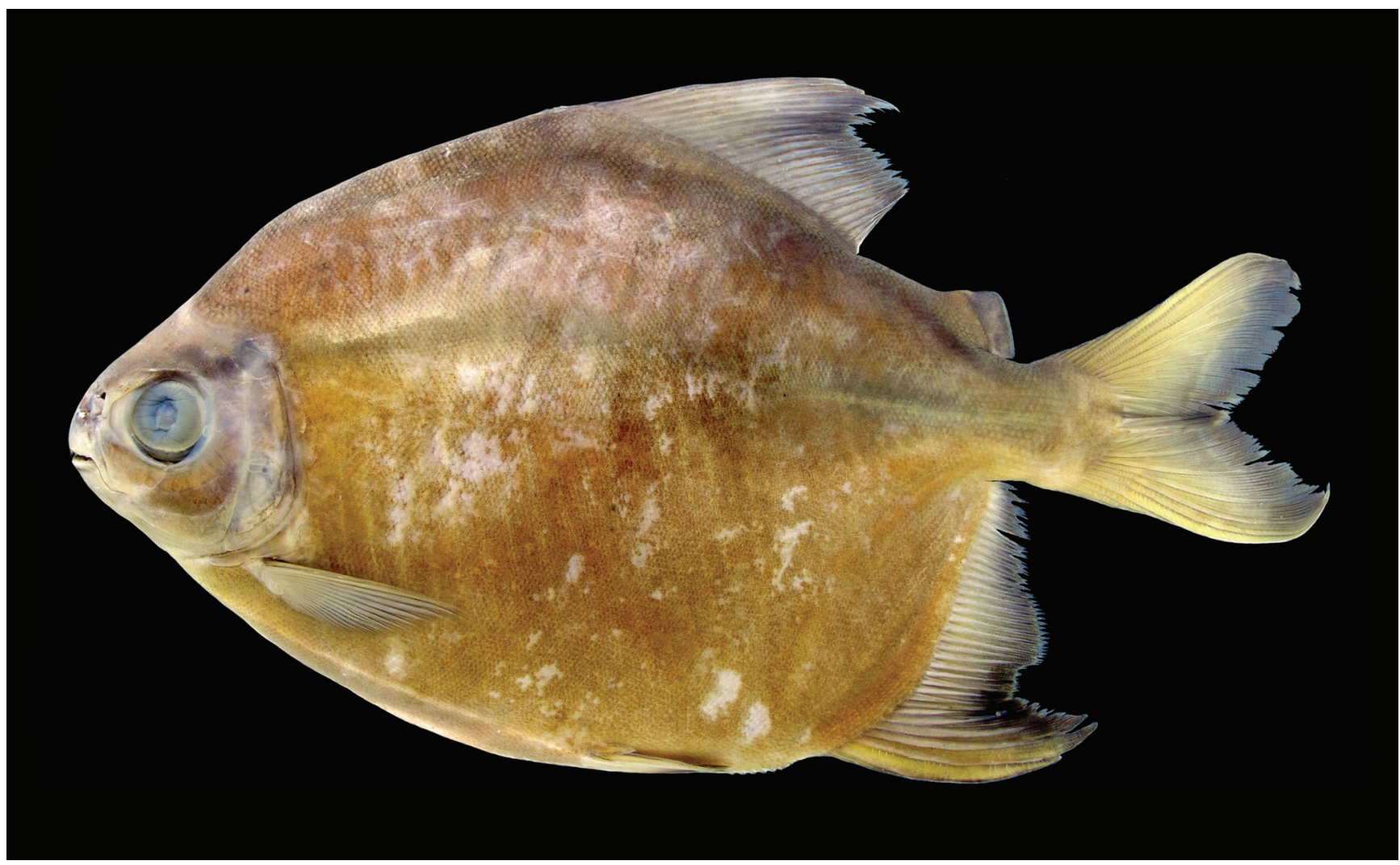

Fig. 1. Tometes camunani, MPEG 23447, holotype, mature male, 224.3 mm SL; Brazil, Pará, Oriximiná, Trombetas basin, rio Erepecuru, upstream of Cachoeira do Chuvisco.

mm SL, rio Trombetas, Iteiro Grande, rapids of Traval, upstream of Cachoeira Porteira, 0046'17'S 56 52'15'W, M. C. Andrade \& D. A. Bastos, 25 Oct 2008; INPA 1238, $43.94 \mathrm{~mm} \mathrm{SL}$, rio Mapuera, Cachoeira Porteira, E. G. Ferreira \& M. Jégu, 10 Apr 1985; INPA $3637,44.74 \mathrm{~mm}$ SL, rio Trombetas, Cachoeira Porteira, 0103'47'S 5702’31’W, E. G. Ferreira \& M. Jégu, 10 Apr 1985.

Diagnosis. Tometes camunani is distinguished from its congeners by having neurocranium with a slight concavity at the level of the frontal bone ( $v s$. concavity absent, dorsal profile of neurocranium straight). Tometes camunani is further distinguished among congeners by: five dentary teeth (vs. 611 in T. makue, and 7-8 in T. lebaili), 81-99 total scales in lateral-line (vs. 63-79 in T. trilobatus and 72-79 in T. lebaili), and 37-42 scales around caudal peduncle (vs. 27-34 in T. trilobatus and 32-36 in T. lebaili). Tometes camunani is also distinguished from $T$. trilobatus by having teeth with central cusp taller and acute ( $v s$. central cusp shorter and with rounded edge). It also differs from $T$. lebaili by a relatively shorter distance from snout to pectoral-fin origin, 19.1-24.2\% SL ( $v S$. 24.5-30.4\% SL), shorter head length, 21.4-25.9\% SL (vs. 26.6$29.8 \% \mathrm{SL}$ ), and by possessing a terminal to scarcely subterminal mouth (vs. upturned mouth). Tometes camunani is further distinguished from T. makue by having 12-26 prepelvic spines (vs. 0-9), 29-44 total spines (vs. 10-23), and by always possessing a pair of symphyseal dentary teeth, behind the main series (vs. symphyseal dentary teeth sometimes absent).

Description. Morphometric data is presented in Table 1. Body extremely compressed, overall aspect of body profile ovoid. Highest body depth at the level of the dorsal-fin origin. Dorsal head profile convex from mouth to vertical line through anterior portion of orbit, from latter point to supraoccipital base with a slight concavity (readily visible in radiography or skeletonized fish), supraoccipital spine straight to slightly convex, and approximately straight from supraoccipital tip to dorsal-fin origin. Dorsal-fin base scarcely convex; body profile straight from posterior end of dorsal-fin base to adipose-fin origin. Ventral profile of head and body (i.e., from lower lip to vertical through anterior portion of orbit and from the latter point to anal-fin origin) slightly convex. Caudal peduncle relatively short, profile of lower caudal peduncle slightly concave.

Snout broadly rounded. Mouth terminal to scarcely subterminal, jaws equally sized. Premaxillary teeth in labial row contacting teeth in lingual row. Five teeth in labial row, two teeth in lingual row (Fig. 2c). Premaxilary and dentary teeth incisiform, relatively robust and shorter when compared with the teeth of Ossubtus and Mylesinus, which are slender 
Table 1. Morphometric data for Tometes camunani, new species. Range for paratypes includes holotype. $\mathrm{N}=$ number of specimens; Min $=$ Minimal; Max. $=$ Maximal; $\mathrm{SD}=$ Standard Deviation.

\begin{tabular}{|c|c|c|c|c|c|c|c|c|c|c|c|}
\hline & \multirow[t]{2}{*}{ Holotype } & \multicolumn{5}{|c|}{ Paratypes } & \multicolumn{5}{|c|}{ Non-type material } \\
\hline & & $\mathrm{N}$ & Min. & Max. & Mean & SD & $\mathrm{N}$ & Min. & Max. & Mean & SD \\
\hline Standard length (mm) & 224.3 & 26 & 126.89 & 384 & 244.4 & - & 11 & 90.8 & 382.0 & 235.0 & - \\
\hline \multicolumn{12}{|c|}{ Percentages of standard length } \\
\hline Body depth & 64.3 & 26 & 56.6 & 65.8 & 62.6 & 2.2 & 10 & 56.2 & 65.7 & 60.0 & 2.8 \\
\hline Head length & 25.3 & 26 & 22.1 & 25.9 & 23.9 & 1.2 & 11 & 21.4 & 25.8 & 23.5 & 1.4 \\
\hline Supraoccipital process & 32.0 & 26 & 28.2 & 32.4 & 30.3 & 1.1 & 11 & 26.2 & 36.5 & 30.3 & 2.7 \\
\hline Predorsal length & 59.5 & 26 & 56.7 & 61.8 & 58.6 & 1.1 & 11 & 52.4 & 61.9 & 57.6 & 2.5 \\
\hline Dorsal-fin base length & 31.2 & 26 & 27.7 & 32.4 & 29.7 & 1.2 & 11 & 27.4 & 31.1 & 29.2 & 1.2 \\
\hline Interdorsal length & 10.9 & 26 & 10.9 & 14.3 & 12.5 & 1.0 & 11 & 11.2 & 13.7 & 12.3 & 0.6 \\
\hline Adipose-fin base length & 7.0 & 26 & 4.5 & 7.0 & 6.0 & 0.5 & 11 & 4.9 & 6.2 & 5.7 & 0.5 \\
\hline Caudal peduncle height & 11.7 & 26 & 10.8 & 12.0 & 11.4 & 0.3 & 11 & 10.5 & 11.9 & 11.2 & 0.5 \\
\hline Anal-fin base length & 32.6 & 26 & 31.2 & 34.4 & 32.7 & 0.8 & 11 & 28.4 & 33.7 & 31.8 & 1.6 \\
\hline Preanal length & 79.6 & 26 & 75.0 & 80.5 & 77.9 & 1.5 & 10 & 73.6 & 81.1 & 76.7 & 2.4 \\
\hline Prepelvic length & 59.5 & 26 & 54.1 & 59.5 & 57.1 & 1.5 & 11 & 53.5 & 58.9 & 56.0 & 2.1 \\
\hline Prepectoral length & 23.2 & 26 & 21.4 & 24.0 & 22.7 & 0.8 & 11 & 19.1 & 24.2 & 22.3 & 1.4 \\
\hline Anal/pelvic distance & 22.3 & 26 & 21.9 & 24.7 & 23.2 & 0.9 & 10 & 20.2 & 23.2 & 22.0 & 1.0 \\
\hline Pelvic/pectoral distance & 36.8 & 26 & 32.8 & 37.2 & 34.9 & 1.1 & 10 & 30.0 & 37.0 & 33.8 & 1.9 \\
\hline Width of peduncle & 3.9 & 26 & 3.6 & 6.4 & 4.8 & 0.7 & 11 & 3.5 & 5.6 & 4.5 & 0.7 \\
\hline Pectoral-fin length & 23.2 & 26 & 20.4 & 23.8 & 22.0 & 1.0 & 11 & 20.0 & 23.5 & 21.7 & 1.2 \\
\hline Pelvic-fin length & 17.7 & 26 & 12.2 & 17.7 & 16.0 & 1.4 & 11 & 13.0 & 17.8 & 15.8 & 1.4 \\
\hline $1^{\text {st }}$ anal-fin lobe length & 29.1 & 15 & 20.2 & 29.3 & 26.0 & 2.5 & 9 & 19.5 & 27.7 & 24.1 & 2.9 \\
\hline $2^{\text {nd }}$ anal-fin lobe length & 14.1 & 8 & 11.1 & 15.5 & 12.9 & 1.4 & 3 & 12.1 & 14.1 & 12.9 & 1.1 \\
\hline Dorsal-fin length & 27.1 & 17 & 24.3 & 34.1 & 29.8 & 2.6 & 7 & 25.1 & 34.9 & 29.0 & 3.3 \\
\hline \multicolumn{12}{|c|}{ Percentages of head length } \\
\hline Snout length & 23.3 & 26 & 23.0 & 32.4 & 28.3 & 3.2 & 9 & 24.6 & 31.5 & 27.5 & 2.8 \\
\hline Interorbital width & 49.8 & 26 & 45.5 & 55.6 & 49.8 & 2.7 & 9 & 46.4 & 53.6 & 50.2 & 2.3 \\
\hline Postorbital distance & 33.5 & 26 & 30.7 & 39.5 & 34.4 & 2.3 & 11 & 32.1 & 40.5 & 34.1 & 2.4 \\
\hline $4^{\text {th }}$ infraorbital width & 14.0 & 26 & 10.7 & 16.2 & 12.6 & 1.3 & 11 & 10.3 & 16.5 & 13.0 & 2.0 \\
\hline Eye vertical diameter & 33.9 & 26 & 32.1 & 40.5 & 36.0 & 2.4 & 9 & 33.1 & 39.5 & 35.5 & 2.4 \\
\hline $3^{\text {rd }}$ infraorbital width & 9.1 & 26 & 11.9 & 20.4 & 15.0 & 2.2 & 9 & 11.8 & 19.4 & 15.9 & 2.5 \\
\hline Cheek gap width & 9.3 & 26 & 8.6 & 12.7 & 10.0 & 1.0 & 11 & 8.2 & 11.4 & 9.8 & 1.0 \\
\hline Mouth length & 13.7 & 26 & 8.2 & 12.2 & 10.0 & 1.0 & 11 & 7.4 & 10.5 & 8.9 & 1.0 \\
\hline Mouth width & 31.5 & 26 & 28.0 & 36.1 & 32.6 & 2.0 & 9 & 27.2 & 36.3 & 32.4 & 3.0 \\
\hline
\end{tabular}

and taller. Premaxillary teeth 1-3 in labial row, each with sharp edge; teeth 1 and 2 separated by gap (Fig. 2c,d). Premaxillary teeth 4 and 5 in labial row shorter and broader than remaining teeth and with sigmoid edge (Fig. 2c,d). Dentary teeth 5, bito tricuspid, with the anterior cusp larger than posterior cusp; posterior cusp externally overlapping anterior cusp of the next tooth (Fig. 2a). Pair of symphyseal dentary teeth always present behind the main series of teeth. Maxillary edentulous.

Scales cycloid, numerous, diminutive and irregular in size, slightly larger in supracleithrum region and on caudal peduncle, decreasing in size toward flanks. Perforated lateralline scales from supracleithrum to hypural plate 74-92 (90). Total perforated lateral-line scales 81-99 (96). Scale rows between dorsal-fin origin and lateral-line 51-68 (68). Scale rows between lateral-line and pelvic-fin insertion 52-75 (73). Circumpeduncular scales 37-42 (40). Ventral serrae reduced, with small prepelvic serrae weakly inserted on abdomen; prepelvic serrae 12-26 (22); simple postpelvic serrae 8-12 (12); double postpelvic serrae 5-8 (8); total serrae 29-44 (42).

Dorsal-fin origin at midbody, preceded by a strong, forward-directed spine. Distal margin of dorsal-fin falcate. Dorsal-fin rays ii-iii,20-22 (iii,21). Anal-fin rays iii-iv,31-34 (iii31). Pectoral-fin rays i,15-18 (i,17). Pelvic-fin rays i,7. Adipose fin present, with moderately long obliquely truncate distal margin. Caudal-fin forked, lobes similarly-sized.

Premaxillary lacking interdigitations at symphysis. Ascending premaxillary process elongated, moderately pointed and oblique in relation to antero-posterior axis of bone (Fig. 2d,e). Lateral premaxillary process short, subrectangular and protruding in relation to fifth tooth in labial row to one-third size of tooth (Fig. 2c). Lateral premaxillary process with a concavity where maxillary is inserted (Fig. 2c). Transversal process aligned with fifth tooth in labial series and protruding to one-fifth its size (Fig. 2c). Four replacement teeth trenches on premaxillary (Fig. 2e). Slender dentary, slightly arched, with 4 or 5 bony lamellae at symphysis (Fig. 2a). Antorbital club-shaped, wide anteriorly and lacking sensory canal. Supraorbital with serrated margins on inner and posterior portions. Infraorbitals 1,5 and 6 with unbranched sensory canal, 2 and 3 with branched sensory canal, and 4 with canal shaped like an inverted Y.

Neurocranium high, triangular, and elongated. Mesethmoid elongated, pointed and triangular anteriorly. Ethmoidal wings elongated, slender antero-posteriorly, positioned on anterior half of mesethmoid. Neurocranium presenting a slight concavity at the level of the frontal. Parietal club-shaped, narrower anteriorly, increasing slightly in width posteriorly. Supraoccipital spine well 


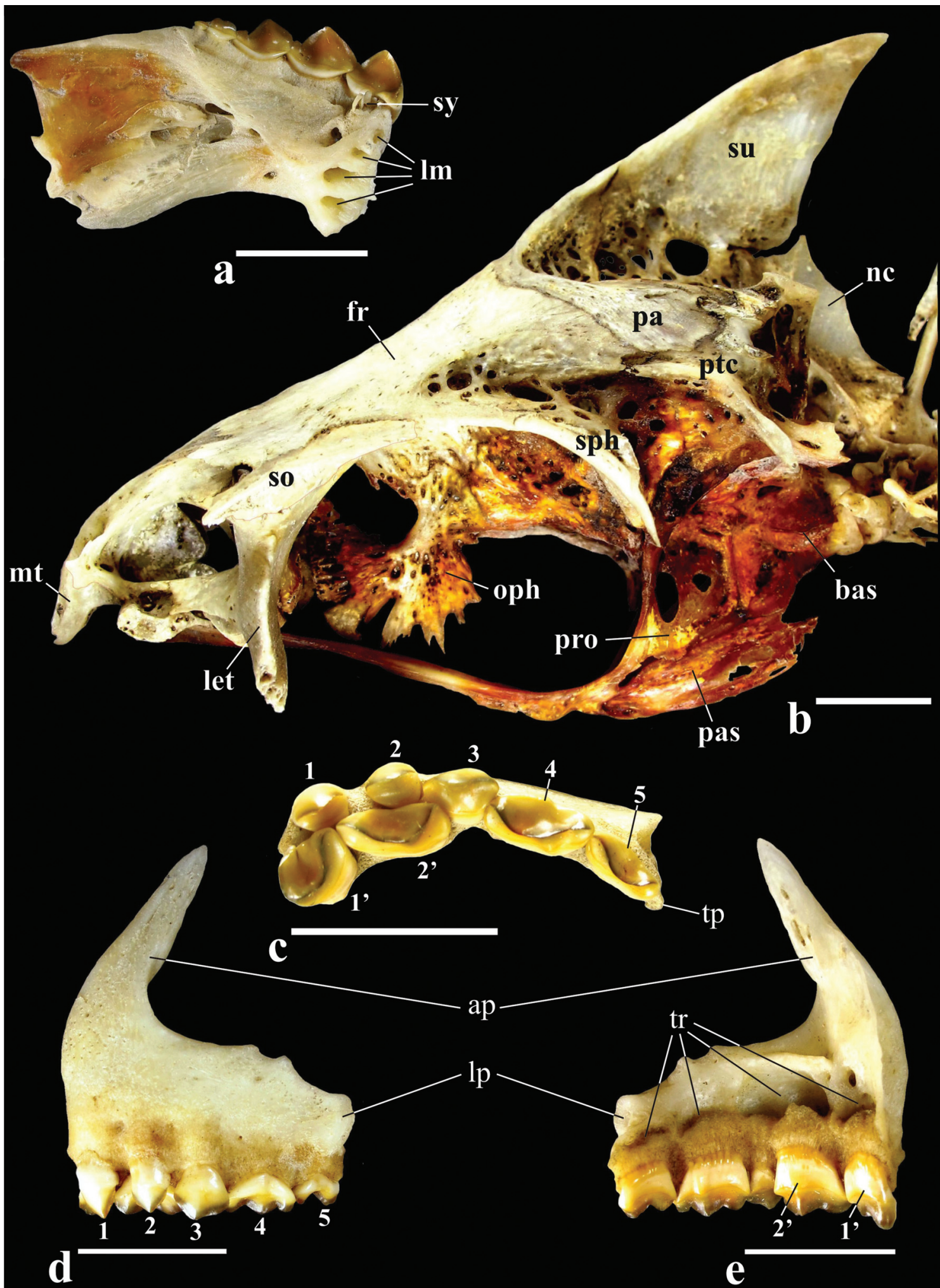

Fig. 2. Tometes camunani, MPEG 23448, $382 \mathrm{~mm} \mathrm{SL}$. a, lingual view of left dentary. b, lateral view of the neurocranium. c-e, ventral, labial and lingual views of the left premaxilla (1-5: teeth in labial row; 1'-2': teeth in lingual row). ap = ascending process of premaxilla; bas = basioccipital; $\mathrm{fr}=$ frontal; let $=$ lateral ethmoid wing; $1 \mathrm{~m}=$ lamellae at symphysis; $1 \mathrm{p}=$ lateral process of premaxilla; $\mathrm{mt}=$ mesethmoid; $\mathrm{nc}=$ neural complex; $\mathrm{oph}=$ orbitosphenoid; $\mathrm{pa}=$ parietal; $\mathrm{pas}=$ parasphenoid $;$ pro $=$ prootic $; \mathrm{ptc}$ $=$ pterotic; $\mathrm{su}=$ supraoccipital; $\mathrm{so}=$ supraorbital; $\mathrm{sph}=$ sphenotic; sy $=$ position of symphyseal tooth; tp $=$ transversal process; $\operatorname{tr}=$ replacement teeth trenches. Scale bar: $10 \mathrm{~mm}$. 
developed, thin, dorsal portion slightly curved. Broad orbital region. Supraorbital with anteroventral margin slightly convex and posteroventral axis slightly downturned. Orbitosphenoid with two laterally compressed bony lamellae, anterior process widened distally and upturned. Orbitosphenoid posteroventral process narrow and projecting ventrally. Ventral margin of orbitosphenoid not reaching parasphenoid. Parasphenoid lacking midventral keel, and with a ventral aperture forming two thin projections parallel to each other across the ventral margins of the prootic and basioccipital. Pterotic triangular, with posterior process directed downward. Sphenotic thin with concave ventral margin; anterior portion wide, narrowing posteriorly from middle portion of bone (Fig. 2b).

First branchial arch with gill rakers elongated, stiff and recurved; 11-14 epibranchial gill rakers; ceratobranchial gill rakers 13-15; one gill raker at cartilage between ceratobranchial and epibranchial. Four branchiostegal rays; three branchiostegal rays on anterior ceratohyal and one on posterior ceratohyal. Total vertebrae 40-42 (41); predorsal vertebrae 10-11 (11); postdorsal vertebrae 14-16 (15). Vertebrae between verticals through last dorsal-fin pterygiophore and first anal-fin pterygiophore 2-3 (3). Supraneurals 6-8 (7).

The gut of $T$. camunani is long and elaborately coiled. The relative length of gastrointestinal tract (RLGIT $=$ GITL/ $\mathrm{SL}$ ) ranges between 4.2 and 5.5 times in SL (mean 4.9).

Color in alcohol. General coloration of body brownish-yellow, darker on dorsal portion. Dorsal, anal and caudal fins hyaline in proximal portion, darker towards margin. Caudal fin with a distal, wide, dark, diffuse band. Adipose fin uniformly brown. Pectoral and pelvic fins hyaline. Juvenile specimens up to 100 $\mathrm{mm}$ SL with a round dark blotch at the humeral region (Fig. 3).

Color in life. Based on observations of freshly preserved specimens: general body color silver, dorsal and anal fins dark-brownish, caudal-fin with a distal, wide, dark band. During the reproductive period, irregularly-shaped red spots evident over flanks, in supracleithrum region and on the anal-fin, mainly in mature males.

Sexual dimorphism. Sexually mature males of Tometes $(\geq 210$ $\mathrm{mm} \mathrm{SL}$ ) are characterized by the presence of an additional anal-fin lobe (Jégu et al., 2002c). In T. camunami, the second lobe is centered on branched anal-fin rays 14 to 16 . The dorsalfin rays of mature males of $T$. camunami are also elongated, forming filaments. Irregularly-shaped reddish blotches are present on the body in mature females, but are more conspicuous in mature males.

Based on the presence of the second anal-fin lobe, the smallest mature male of Tometes camunani observed measured $210 \mathrm{~mm}$ SL, which is similar to the size of the smallest recorded mature male of T. makue (Jégu et al., 2002b). In contrast, a second analfin lobe is only evident in specimens of Tometes trilobatus and T. lebaili at about $300 \mathrm{~mm}$ SL (Jégu et al., 2002a,c). In some mature males of Tometes, the distal portions of the rays of the second anal-fin lobe have a pair of stiff, laterally curved hooks, which is similar to the condition observed in Mylesinus paraschomburgkii (Jégu et al., 1989: fig. 8). Anal-fin rays with stiff hooks were observed in specimens of Tometes trilobatus, $T$. makue, and T. lebaili at about $400 \mathrm{~mm}$ SL (Jégu et al., 2002a,b,c). Similarly-sized mature males of Tometes camunani (MPEG23448, $382 \mathrm{~mm} \mathrm{SL}$; MPEG 23440,384 mm SL), however, lack stifflaterally curved hooks on second anal-fin lobe.

Distribution. Tometes camunani is known from the upper rio Trombetas and its tributaries rio Mapuera, rio Cachorro, and rio Erepecuru draining the Guiana Shield, Pará State, Brazil (Figs. 4-5).

Etymology. Species refers to "camunani", its common name in the Wai-Wai language. The Wai-Wai inhabit the upper rio Trombetas basin, and consider the species of great cultural importance. The common name is also employed by local quilombolas (i.e., inhabitants of settlements founded by escaped slaves of African origin), who capture the fish using as bait the fruit of the camu-camu tree (Myrciaria dubia, Myrtaceae).

Ecological notes. The diet of the two smallest specimens examined (MPEG 23449 and MPEG 23450; 90.8 and $133 \mathrm{~mm}$ SL, respectively) was composed mainly of fragments of Podostemaceae and benthic macroinvertebrates (Leptophlebiidae, Simuliidae and Chironomidae). The largest specimens examined (MPEG 23448; MPEG 23450; MPEG 23451; MPEG 23452; $\mathrm{n}=6,175-382 \mathrm{~mm} \mathrm{SL}$ ) consumed mainly leaves of Podostemaceae, and fragments of grass and whole seeds of Myrtaceae and Fabaceae. Oxyuroid nematodes (Rondonia rondoni) were also found in the gastrointestinal tract of all dissected specimens.

\section{Discussion}

All genera of the Myleus group occur exclusively in shield drainages, and are rheophilic and phytophagous, feeding mainly on Podostemaceae (Jégu, 2004). Tometes camunani occurs in association with swift-flowing rapids and rocky outcrops in clear water rivers of the upper rio Trombetas. During the dry season, schools of large specimens (about $300 \mathrm{~mm} \mathrm{SL}$ ) were observed swimming against the current along very shallow stretches of rapids (depth $\leq 0.35 \mathrm{~m}$ ).

Given the habitat hyperspecificity of Tometes camunani to river stretches with rapids in the rio Trombetas basin, it seems that the slow-flowing lower reaches of this basin and the Rio Amazonas channel are barriers to its dispersal. Based on personal observations of the last author around Cachoeira Porteira during the 2007 low-water period, larval and small juveniles of Mylesinus and Tometes are restricted to within $200 \mathrm{~m}$ downstream of the rapids. A high concentration of larval and juvenile specimens of Mylesinus and Tometes was observed within the rapids among leaves of Podostemaceae, suggesting positive rheotropism from a larval stage. As a consequence, the species is likely sensitive to the impacts caused by the construction of 


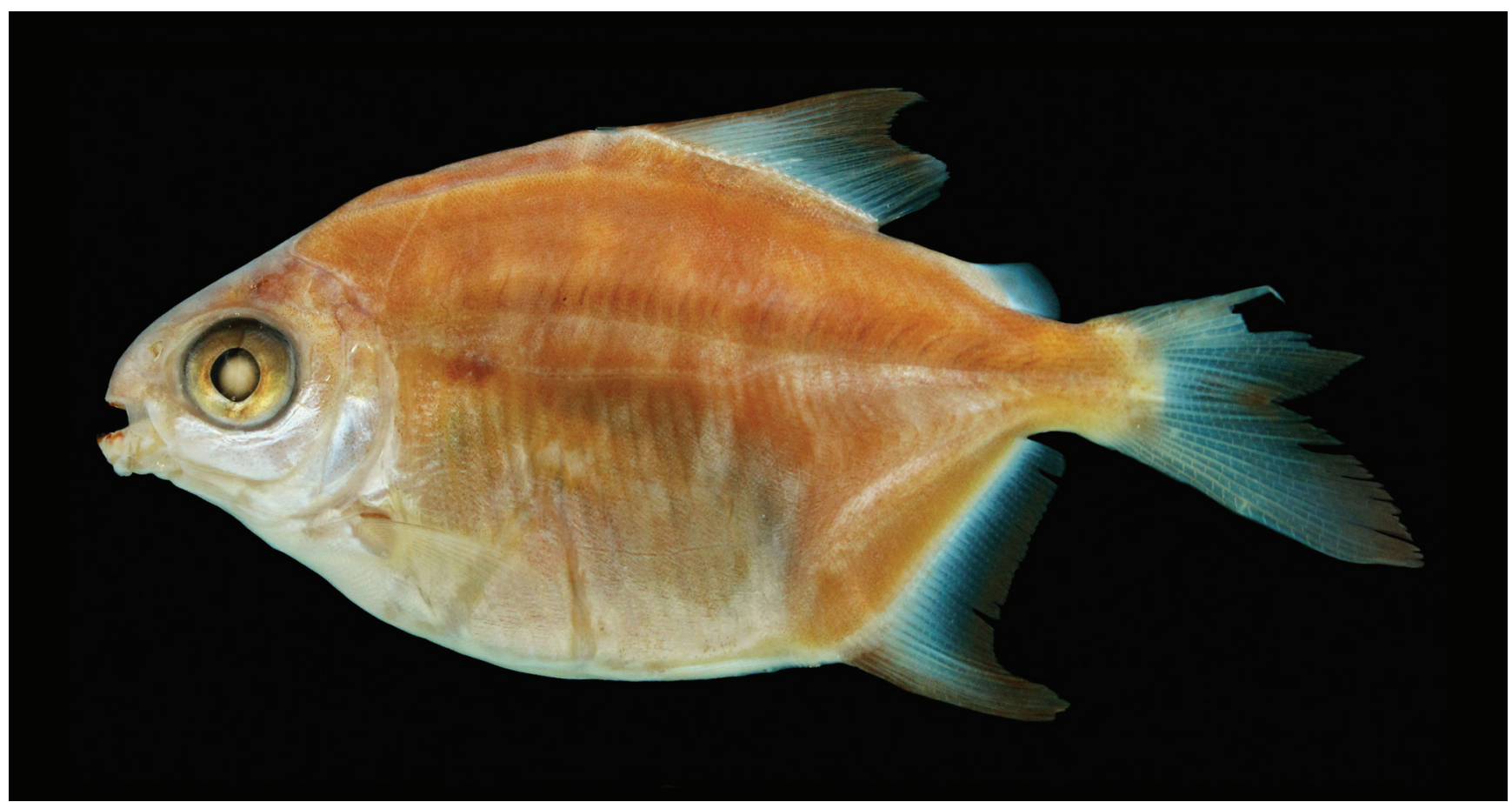

Fig. 3. Tometes camunani, INPA 3637, juvenile, 44.7 mm SL; Brazil, Pará, Oriximiná, rio Trombetas, Cachoeira Porteira.

hydroelectric dams. Like its congeners and several other serrasalmid genera, T. camunani has a typical "shield" distribution pattern (i.e., restricted to shield areas of northern cis-Andean South America; Lima \& Ribeiro, 2011). Considering the ecoregions for the Guiana Shield proposed by Vari \& Ferraris (2009), T. camunani is endemic to the Brazil-Pará ecoregion.

Like several other species occurring in shield areas, the complete distribution and vagility of Tometes

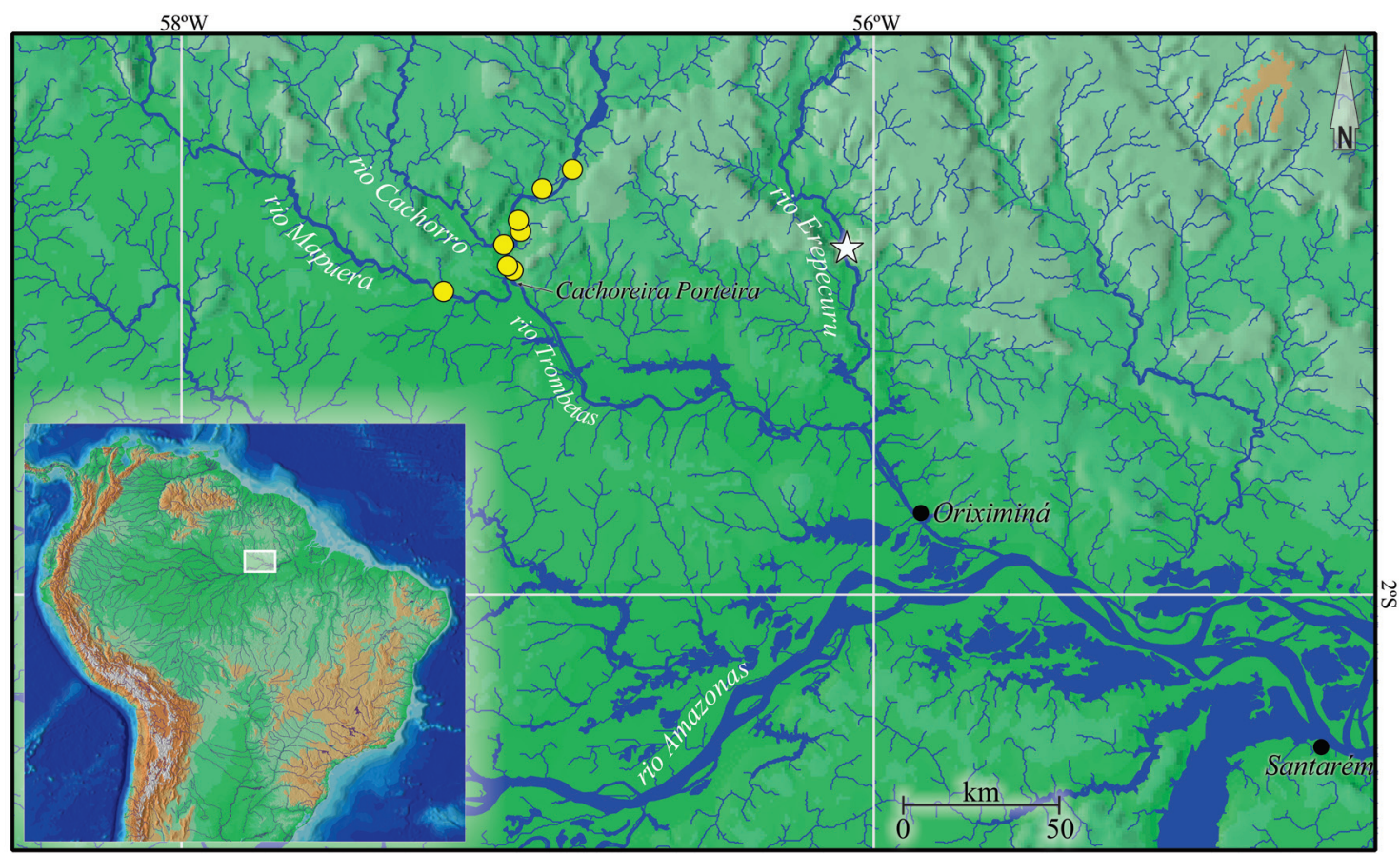

Fig. 4. Map of upper rio Trombetas basin and adjoining areas, showing the distribution of Tometes camunani. Star indicates type locality. 


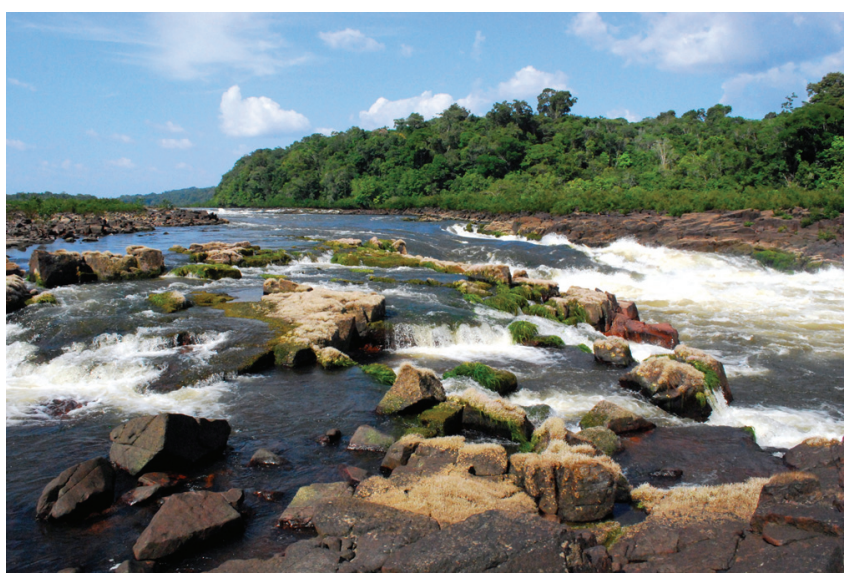

Fig. 5. Typical habitat of Tometes camunani, rapids and waterfalls in rio Trombetas basin, Pará, Brazil. Rocks are covered with Podostemaceae, rheophilic aquatic plants typical of the diet of species of Tometes (Photo by D. Bastos, 2008).

camunani is poorly understood at present time. Future studies involving molecular analysis of $T$. camunani and other fishes typical of shield areas are needed to evaluate the roles of dispersal and vicariance in the distributional patterns observed across rivers draining the Brazilian and Guiana Shields.

\section{Identification key to species of the Myleus group}

1. Frontal premaxillary teeth form a continuous row; pair of symphyseal dentary teeth very small; dentary teeth molariform to incisiform with a wide base; prepelvic serrae pronounced, forming an abdominal keel

\section{2}

1'.Frontal premaxillary teeth clearly separated; pair of symphyseal dentary teeth large (when present); dentary teeth incisiform with a slender base, bi- to trilobed with the anterior lobe inserted into a groove of the tooth immediately anterior; prepelvic serrae (when present) reduced to a row of spines, not forming an abdominal keel

2. Branched dorsal-fin rays $18-20$ Myleus setiger (tributaries of the Guiana and Central Brazilian Shield; from Maroni basin to coastal rivers of western Guyana; rightbank tributaries of Orinoco on Guiana Shield)

2'.Branched dorsal-fin rays 24 .. Myleus knerii (Steindachner, 1881) (Maroni River basin; known only from type specimen)

3. Premaxillary teeth in labial row similarly sized, very compressed anteroposteriorly, and with cusps aligned

3 '. Two posteriormost premaxillary teeth in labial row shorter and wider than anterior ones, not compressed anteroposteriorly, and with sinuous cusps ........................ 7

4. Mouth markedly downturned; prepelvic spine absent; branched anal-fin rays 22-25; dentary with four teeth in labial row; humeral spot triangular and pointed ventrally Ossubtus xinguense (rio Xingu basin)

4'.Mouth terminal; prepelvic spines present; branched analfin rays greater than 25; dentary with more than five teeth in labial row; humeral spot absent or rounded, when present

5. Pair of symphyseal dentary teeth present; dentary with 710 teeth in labial row; lateral-line scales 60-79; scales around caudal peduncle 30-34 Mylesinus paucisquamatus Jégu \& Santos, 1988 (rio Tocantins basin)

5 '.Pair of symphyseal dentary teeth absent; dentary teeth in labial row 8-14; lateral-line scales 75-96; scales around caudal peduncle $34-41$ ... 6

6. Snout length $31-38 \%$ of HL; eye diameter $30-34 \%$ of HL Mylesinus paraschomburgkii (left-bank tributaries of rio Amazonas from Uatumã basin to rio Araguari basin)

6'. Snout length $41 \%$ of HL; eye diameter $28 \%$ of HL Mylesinus schomburgkii Valenciennes, 1850 (río Essequibo basin; known only from type specimen)

7. Mouth clearly upturned; 7-8 dentary teeth in labial row Tometes lebaili (río Maroni and río La Mana basins)

7'.Mouth terminal; 5-11 dentary teeth in labial row ............... 8

8. Dentary teeth in labial row 6-11; prepelvic spines 0-9; pair of symphyseal teeth on dentary absent in some specimens Tometes makue (rio Negro and rio Orinoco basins)

8 '.Dentary teeth in labial row 5; more than 9 prepelvic spines; pair of symphyseal teeth on dentary always present 9

9. Dorsal profile of neurocranium straight; lateral-line scales 63-79; scales around caudal peduncle 27-34; central cusp of all teeth shorter and with rounded edge .. Tometes trilobatus

(Eastern Guiana Shield drainages from Oyapock basin to Araguari basin)

9'.Neurocranium with a slight concavity at the level of frontals; lateral-line scales 81-99; scales around caudal peduncle 37-42; central cusp of all teeth taller and acute .. Tometes camunani new species (rio Trombetas basin)

Comparative material examined. Tometes lebaili: MNHN 20012384, holotype; $108.6 \mathrm{~mm}$ de SL, village Antecume Pata, Maroni River, 03¹8'06”N 5404'54'W; MNHN 1993-3452, 251 mm SL, French Guyana, St. Laurent du Maroni, Maripasoula, Maroni River; MNHN 1993-3453, 202 mm SL, French Guyana, St. Laurent du Maroni, Maripasoula, Maroni River; MNHN 1998-0294, 119 mm SL, French Guyana, St. Laurent du Maroni, Saut Fracas, Mana River, 0446'01'N 5339'00'W; MNHN 1998-0298, 271 mm SL, French Guyana, St. Laurent du Maroni, Saut Fracas, Mana river, 0446’01'N 5339'00"W; MNHN 1998-1347, 5, 42-72 mm SL, French Guyana, St. Laurent du Maroni, Antecume Pata, rio Maroni, 03¹8'00"N 5404'01"W; MNHN 1999-0641, 282 mm SL, French Guyana, St. 
Laurent du Maroni, Antecume Pata, Maroni River. Tometes makue: Brazil, Amazonas, São Gabriel da Cachoeira, rio Negro, 0007'49”S 6705'21'"W. INPA 7344, holotype; 240 mm SL; INPA 3179, 125 mm SL; INPA 4913, 370 mm SL; INPA 4914, 2, 330-355 mm SL; INPA 4915, 2, 138-158 mm SL; INPA 4916, 2, 239-307 mm SL; INPA 4917, 261 mm SL; INPA 4920, 4, 172-229 mm SL; INPA 4924, 12, 53-78 mm SL. Tometes trilobatus: MNHN A.8650, lectotype, $340 \mathrm{~mm}$ SL, syntype of Tometes trilobatus Valenciennes; MNHN A.8649, paralectotype, $370 \mathrm{~mm}$ LS, syntype of Tometes trilobatus Valenciennes; MNHN A.8651, 274 mm SL, holotype of Tometes unilobatus Valenciennes; MNHN 1998-0099, 248 mm SL, French Guyana, Cayenne, Saut Maripa, rio Oyapock, 0346'01'N 51 54'00"W; MNHN 1981-0508, 149 mm SL, French Guyana, Cayenne, Saut Maripa, rio Camopi; MNHN 1998-0307, 5, 36-86 $\mathrm{mm}$ SL, French Guyana, Cayenne, Saut Maripa, rio Camopi, 0351'00"N 05151'00"W; INPA 19967, 116 mm SL, Brazil, Amapá, Macapá, Rio Araguari, Cachoeira Santa Rosa. Mylesinus paraschomburgkii: INPA 1226, holotype, 250 mm SL, Brazil, Pará, Rio Trombetas downstream of the Cachoeira Vira Mundo; INPA 4498, 6, 136-273 mm SL, Brazil, Amapá, Laranjal do Jari, Rio Jari downstream of the Cachoeira São Raimundo, $01^{\circ} 07^{\prime} 12^{\prime \prime S ~ 5240 ' 03 " W ; ~}$ INPA 4471, $214 \mathrm{~mm}$ SL, Brazil, Pará, rio Trombetas, upstream of the Cachoeira Porteira, 0057'01' 'S 5701'13'W; INPA 4466, 6, 99-277 $\mathrm{mm}$ SL, Brazil, Pará, rio Trombetas, upstream of the Cachoeira Porteira, 0057'01'S 5701'13”'W; INPA 3047, 6, 127-257 mm SL, Brazil, Amazonas, Presidente Figueredo, rio Uatumã, 02 02 '03"S 6001'29"W. Mylesinus paucisquamatus: INPA 1808, holotype, 162 mm SL, Brazil, Pará, Tucuruí, rio Tocantins, igarapé Jatobal, 034' 57'S 4940'20”W. Utiaritichthys longidorsalis: INPA 3638, holotype, $198 \mathrm{~mm}$ SL, Brazil, Mato-Grosso, Madeira basin, Aripuanã, rio Aripuanã, downstream of the Cachoeira Dardallenos, $10^{\circ} 10^{\prime} 00^{\prime} \mathrm{S} 59^{\circ} 27^{\prime} 33^{\prime \prime W}$. Utiaritichthys sennaebragai: MZUSP 82021, 2, 146.4-154.5 mm SL, Brazil, Mato-Grosso, Tapajós basin, Sapejal, rio Juruena, Usina. Ossubtus xinguense: INPA 6535, holotype, $170 \mathrm{~mm}$ SL, Brazil, Pará, Altamira, rio Xingu, 03¹2'11”S 52¹2'23”W. Myleus setiger: INPA 3781, 2, 197.8-282.4 mm SL, Brazil, Pará, Tucuruí, Capuarana, rio Tocantins, 0345'57”S 4940’20"W, INPA-2347 381.97 mm SL, Brazil, Pará, Tucuruí, rio Tocantins, $03^{\circ} 45^{\prime} 57^{\prime \prime} \mathrm{S} 49^{\circ} 40^{\prime} 20^{\prime \prime} \mathrm{W}$.

\section{Acknowledgments}

We are grateful to the ICMBio staff of the Reserva Biológica do Trombetas for their hospitality and assistance during the early phases of our work. Thanks to D. Bastos, L. Melo, G. Klein, J. Carvalho Jr., and V. Isaac for logistical help and aid during the collection of specimens, and A. J. S. Jesus (UFPA) for having provided the figure 4. We also thank L. Rapp PyDaniel, J. Zuanon, A. Canto, R. Oliveira and M. Rocha (INPA), W. Wosiacki, L. Peixoto and G. Dutra (MPEG) and J. Figueiredo, O. Oyakawa and M. Gianete (MZUSP) for their help during visits to their respective institutions. We are grateful to $\mathrm{P}$. Pruvost and R. Causse (MNHN) for the loan of comparative material. Special thanks to F. C. T. Lima (ZUEC), M. H. Sabaj Pérez (ANSP) and an anonymous reviewer for valuable suggestions and comments on the manuscript. Thanks are also due to Jens Hegg for the English revision. MCA was funded by Coordenação de Aperfeiçoamento de Pessoal de Nível Superior (CAPES), and TG receives a productivity grant from CNPq (process: 308278/2012-7).

\section{Literature Cited}

Brito, P. M., F. J. Meunier \& M. E. C. Leal. 2007. Origine et diversification de l'ichtyofaune néotropicale: une revue. Cybium, 31: 139-153.

Ferreira, E. J. G. 1993. Composição, distribuição e aspectos ecológicos da ictiofauna de um trecho do rio Trombetas, na área de influência da futura UHE Cachoeira Porteira Estado do Pará, Brasil. Acta Amazônica, 23: 1-89.

Jégu, M. 2003. Subfamily Serrasalminae (Pacus and Piranhas). Pp. 182-196. In: Reis, R. E., S. O. Kullander \& C. J. Ferraris (Eds.). Check list of the freshwater fishes of South and Central America. Porto Alegre, Edipucrs.

Jégu, M. 2004. Taxinomie des Serrasalminae phytophages et phylogénie des Serrasalminae (Teleostei: Characiformes: Characidae). Unpublished Ph.D. Dissertation. Muséum National d'Histoire naturelle, Paris.

Jégu, M. \& G. M. Santos. 2002. Révision du statut de Myleus setiger Müller \& Troschel, 1844 et de Myleus knerii (Steindachner, 1881) (Teleostei: Characidae: Serrasalminae) avec une description complémentaire des deux espèces. Cybium, 26: 33-57.

Jégu, M. \& P. Keith. 2005. Threatened fishes of the world: Tometes lebaili (Jégu, Keith \& Belmont-Jégu 2002) (Characidae: Serrasalminae). Environmental Biology of Fishes, 72: 378.

Jégu, M., G. M. Santos \& E. J. G. Ferreira. 1989. Une nouvelle espèce du genre Mylesinus (Pisces, Serrasalmidae), $M$. paraschomburgkii, décrite des bassins du Trombetas et du Uatumã (Brésil, Amazonie). Revue d'Hydrobiologie Tropicale, 22: 49-62.

Jégu, M., G. M. Santos \& E. Belmont-Jégu. 2002b. Tometes makue n. sp. (Characidae: Serrasalminae), une nouvelle espèce du bouclier guyanais décrite des bassins du Rio Negro (Brésil) et de l'Orénoque (Venezuela). Cybium, 26: 253-274.

Jégu, M., G. M. Santos, P. Keith \& P. Y. Le Bail. 2002c. Description complémentaire et réhabilitation de Tometes trilobatus Valenciennes, 1850, espèce-type de Tometes Valenciennes (Teleostei: Characidae: Serrasalminae). Cybium, 26: 99-122.

Jégu, M., P. Keith, \& E. Belmont-Jégu. 2002a. Une nouvelle espèce de Tometes (Teleostei: Characidae: Serrasalminae) du bouclier guyanais, Tometes lebaili n. sp. Bulletin Francais de la Peche et de la Pisciculture, 364: 23-48.

Junk, W. J. \& J. A. S. Mello. 1990. Impactos ecológicos das represas hidrelétricas na bacia amazônica brasileira. Estudos Avançados, 4: 126-143.

Kner, R. 1860. Zur Familie der Characinen. III. Folge. Der ichthyologischen Beiträge. Denkschriften der MathematischNaturwissenschaftlichen Classe der Kaiserlichen Akademie der Wissenschaften in Wien, 18: 9-62.

Lima, F. C. T. \& A. C. Ribeiro. 2011. Continental-Scale Tectonic Controls of Biogeography and Ecology. Pp. 145-164. In: Albert, J. S. \& R. E. Reis (Eds.). Historical Biogeography of Neotropical Freshwater Fishes. University of California Press, Berkeley.

Ortí, G., A. Sivasundar, K. Dietz \& M. Jégu. 2008. Phylogeny of the Serrasalmidae (Characiformes) based on mitochondrial DNA sequences. Genetics and Molecular Biology, 31: 343-351.

Pagezy, H. \& M. Jégu. 2002. Valeur patrimoniale de Serrasalminae herbivores du Haut Maroni (Guyane française), approches biologique et socio-culturelle en pays Wayana. Bulletin Francais de la Peche et de la Pisciculture, 364: 49-69.

Pagezy, H. \& M. Jégu. 2003. Valeur sociale et culturelle des kumaru, poissons du Haut Maroni, Guyane française: implications dans 
un contexte de pollution au mercure. Pp. 133-136. In: Geistdorfer, A., J. Matras-Guin \& J. Ivanoff (Eds.). La mer Dévorée. Le poisson bon à manger, le poisson bon à penser. Collection Kétos, White Lotus Press, Bangkok.

Pagezy, H. \& M. Jégu. 2010. Les dessins d'enfants, révélateurs des rapports de la société à l'environnement: l'exemple de la pêche aux kumaru chez les Indiens Wayana de Guyane Française. Pp. 199-215. In: Barone-Visigalli, E. \& A. Roosevelt (Eds.). Amaz'hommes, Sciences de l'homme et Sciences de la Nature en Amazonie. Cayenne, Ibis Rouge Editions.

Valenciennes, A. 1850. Des genres Tomète, Mylée et Mylésine. Pp. 225-237. In: Cuvier G. \& A. Valenciennes. Histoire naturelle des Poissons. Tome vingt-deuxième, Suite du livre vingtdeuxième, Suíte de la famille des Salmonoïdes, Paris et Starsbourg, Bertrand et Levrault.

Vari, R. P. \& C. J. Jr. Ferraris. 2009. Fishes of the Guiana Shield. Pp. 9-18. In: Vari, R. P., C. J. Jr. Ferraris, A. Radosavljevic \& V. A. Funk (Eds.). Checklist of the freshwater fishes of the Guiana Shield. Bulletin of the Biological Society of Washington, 17: 195.

Weitzman, S. H. 1962. The osteology of Brycon meeki, a generalized characid fish, with an osteological definition of the family. Stanford Ichthylogical Bulletin, 8: 1-77.

Submitted January 11, 2013 Accepted March 27, 2013 by Fabio Di Dario Published June 28, 2013 